\title{
Strategic Leadership and Organizational Performance: A Critical Review of Literature
}

\author{
Alex A. Jaleha \\ Vincent N. Machuki, PhD \\ School of Business, University of Nairobi, Kenya
}

Doi:10.19044/esj.2018.v14n35p124 URL:http://dx.doi.org/10.19044/esj.2018.v14n35p124

\begin{abstract}
Effective strategic leadership is considered as a major ingredient for the successful performance of any organization operating in the ever dynamic and complex environment of the $21^{\text {st }}$ century. In the context of information uncertainty and resource scarcity, strategic leadership is required to confront the reality of environmental turbulence and a continuous need for appropriate organizational change in order to achieve performance goals. Most of the conceptual and empirical studies have shown that strategic leadership actions significantly influence performance. Despite its importance, studies have demonstrated that the influence of strategic leadership on organizational performance is contingent upon situational constraints or random effects. To date, very little empirical research has analyzed the direct and indirect relationship between strategic leadership, external environment, organizational change and performance. This paper seeks to unearth this research gap by critically reviewing relevant conceptual and empirical literature to bring out the possibility that the external environment and organizational change could influence the relationship between strategic leadership and organizational performance. The paper advances the emerging postulations which anchor a conclusion that the direct effect of strategic leadership on performance is contested and hence inconclusive due to possible moderating and mediating influence of the external environment and organizational change respectively. It is hoped that the paper's postulations would guide empirical research in various contexts to hasten addressing of the extant knowledge gaps.
\end{abstract}

Keywords: Strategic leadership, Organizational change, External environment, Organizational performance 


\section{Introduction}

The core purpose of strategic leadership theory and research is to understand how much influence top executives have over performance (Singh et al. 2016). Empirical and conceptual studies have shown that strategic leadership actions significantly influence performance (Quigley \& Graffin, 2017; Ireland \& Hitt, 1999). Unfortunately, other studies conclude that their actions are impeded by situational constraints, inertia or random effects, such that they don't have much leeway over performance (Fitza, 2017; Haveman, 1992). These divergent findings indicate either a lack of evidence in establishing a direct association between strategic leadership and performance or of the many confounding variables that make it difficult to demonstrate a clear cause and effect (Knies et al., 2016). Hambrick \& Quigley (2014) point out that scholars are yet to agree on the conceptualization and operationalization of contextual conditions strategic leaders face.

Various scholars have argued that methodological and statistical limitations, unavailability of relevant control variables and contexts have systematically undermined the effect of strategic leadership on performance (Fitza, 2017; Hambrick \& Quigley, 2014; Blettner et al., 2012; Thomas, 1998). Boal \& Hooijberg (2001) observe that studies on strategic leadership are limited since many have used demographic variables as substitutes for moderating or mediating variables. Crossan et al., (2008) argue that many studies have excluded critical organizational and environmental variables that might moderate or mediate such a relationship. Additionally, empirical literature has solely examined the impact of strategic leadership at the micro levels without integrating both the micro and macro perspectives of leadership (Bornardi et al., 2018; Kim et al., 2014).

To date, very little research has analyzed the direct and indirect relationships between strategic leadership, external environment, organizational change and performance variables. Morales et al., (2008) admit by pointing out that few studies on strategic leadership have systematically traced the causal path of its effect on performance by examining the intermediate influence of different strategic variables. This paper seeks to fill these research gaps by reviewing conceptual and empirical literature on how the external environment and organizational change as moderators and mediators respectively could influence the relationship between strategic leadership and organizational performance.

The theoretical foundation of this paper is Hambrick \& Mason's (1984) upper echelons theory (UET). The theory assumes that performance is significantly influenced by the idiosyncratic background characteristics, values and knowledge of members of the dominant coalition occupying influential managerial positions in the apex organization (Quigley \& Hambrick, 2015). Some scholars have dismissed the use of demographics as 
proxies as they don't provide greater insight into the actual activities of senior managers, and the actual processes by which executives impact organizational outcomes (Boal \& Hooijberg, 2001). The contingency theory paradigm, where aligning the characteristics of the organization to the environment or context results in enhanced performance, (Lawrence \& Lorsch 1967), also forms a theoretical base of this paper. Since this alignment leads to positive performance, seeking the ideal alignment becomes a priority undertaking by organizations (Donaldson, 2001). The theory highlights the relationship between two variables as being influenced by other variables, thus no comprehensive list of best strategic choices will apply to all organizations and circumstances (Ginsberg \& Venkatraman, 1985).

This paper is anchored on the complexity theory which illustrates how complex structures adapt and change. Its main postulation is how order generating rules emerge in inherently fluid and non - linear dynamical systems functioning on the edge of chaotic and unpredictable changes (Burnes, 2005). The idea of organizational change being planned is contested, while the emergent approach where power and continuous organizational changes determine organizational survival forms a key premise of the theory (Stacey, Griffin \& Shaw, 2002). It views organizations as complex systems capable of self - adjusting to continuous organizational changes as a result of the unpredictable and dynamic phenomenon of the external environment (Brown \& Eisenhardt 1997). The implication is that strategic leadership needs to focus on building organizations that can quickly evolve effective adaptive solutions.

The paper is also anchored on the Environment Dependency Theory (EDT) advanced by Ansoff \& Sullivan (1993). The theory postulates that performance is enhanced when organizations are able to anticipate and respond to environmental shifts. The open systems and institutional theories anchor the EDT. The open systems theory posits a close interaction between the organization's internal and external environment. This implies that strategic leaders can better understand the importance of the external environment and in turn, on its overall influence on performance (Scott, 2005). Institutional theory suggests that the environment exerts pressures on organizations leading to different responses as they seek legitimacy in order to survive and prosper (Scott, 2005). The theory postulates that market dynamics and institutionalized managerial practices are critical factors that reduce environmental uncertainty and enhance performance (North, 1991). Thus, strategic leaders as institutional players need to synthesize and interpret strategic stimulus options and formulate, implement and monitor the appropriate strategic responses (Scott, 2005).

To bring out the unresolved issues and advance the conceptualization to guide further research, the paper is organized along the relevant thematic areas. An understanding of the variables is presented followed by a critical 
examination of the relevant literature along the theoretical, conceptual and empirical lines. A proposed conceptual framework is presented which depicts the emerging propositions and areas for further on the basis of which a conclusion is drawn.

\section{Strategic Leadership}

The study and scope of strategic leadership focuses on a small group of executives referred to as the chief executive officers (CEO), top management teams (TMT) and the board of directors who have the overall responsibilities of an organization (Lord et al, 2016; Strand, 2014). Despite its importance to performance, strategic leadership researchers and practitioners are yet to agree on a common definition (Allio, 2013). Irrespective of the diverse terminologies and disconnected constructs used in past strategic leadership studies, Bass (2007) defines it as a group of chief executive officers (CEO) who set overall policies for acquiring and integrating resources for an organization.

Ireland \& Hitt (1999) conceptualize it as a set of unique capabilities of anticipating, envisioning, maintaining flexibility, thinking in a strategic way, and empowering employees to generate innovative ideas that lead to high performance. House \& Aditya (1997) define it as an activity that is directed towards giving purpose to organizations. Boal \& Hooijberg (2001) views it as the ability to create and maintain absorptive and adaptive capacities and the ability to discern environmental opportunities through their managerial wisdom. Rowe \& Nejad (2009) define it as an activity of communicating the shared values and a clear vision to employees, and the ability to make decisions with minimum organizational controls.

A review of the literature on the various definitions of strategic leadership reveals the different roles played and the unique capabilities strategic leadership possess for accomplishing organizational tasks that are beyond that of one individual, micro level or what Meindl \& Ehrlich (1987) refer to as heroic leadership. By going beyond heroism, this paper defines strategic leadership from the perspective of an organization's macro level or the top management team. Specifically, it concerns integrating the micro and macro perspectives of leadership and the organizational context (Crossan et al., 2008; Boal \& Hooijberg, 2001). Conceptualizing strategic leadership from a macro view highlights how the two levels are integrated. Thus, this paper adopts Ireland \& Hitt (1999) and Hagen et al's., (1998) conceptually accepted and empirically validated definition of strategic leadership that's based on the unique abilities of anticipating, envisioning, maintaining flexibility, thinking strategically and empowering employees to create new inventions that lead to organizational transformations or changes and ultimately improvement in 
performance. This paper adopts the upper echelon theory (UET) which builds upon the concept of strategic leadership

Strategic leadership is concerned with capabilities of creating a sense of purpose and direction, critical enablers that allow interaction with key internal and external stake holders in pursuit of high performance (House \& Aditya 1997). Carter \& Greer (2013) view of strategic leadership is anchored on the thinking and visionary capabilities of strategic leadership whose aim is to create an organization that is transformative. Shoemaker \& Krupp (2015) argue that strategic leadership is not only concerned with the possession of unique abilities that allows for the absorption and learning of new information and ideas, but having the adaptive capacity to appropriately respond to the dynamism and complexity of the external environment. They further posit that such abilities allow strategic leaders to continuously and tactically adjust the organization in response to the uncertain environment.

Scholars have generally enriched the quality of strategic leadership with insights from charismatic, transformational, visionary, adaptive, transactional, servant, reflective, transcendental and empowered leadership respectively (Bass, 1985; Waldman et al., 2001; Castelli, 2016; Crossan et al., 2008). Adaptive, transactional, servant, reflective, transcendental and empowered leadership can be viewed as types of charismatic, visionary and transformational styles that focus on the leadership of the self, others and of the organization respectively (Crossan et al., 2008; Boal \& Hooijberg, 2001; Waldman et al., 2001; Bass, 1985). Specifically, strategic leadership has been described by most scholars as encompassing a core of critical practices, which include: determining the long term goals of the organization; exploring and exploiting an organization's core capabilities; managing the human and social assets; inculcating a sustainable organizational culture; emphasizing ethical values and formulating and implementing balanced control systems that will not hinder continuous transformation but at the same time ensure organizational stability (Ireland \& Hitt1999; Hagen et al., 1998).

Most recent studies on the influence of strategic leadership on performance suggest that it is substantial (Quigley \& Graffin, 2017). Thus, it is critical for scholars to pinpoint essential strategic leadership behaviours or practices that will lead to high levels of performance (Mutia 2015; Jansen et al., 2009; Jouste \& Fourie 2009). Unfortunately, due to inertial forces in the form of organizational and other environmental constraints, some studies have demonstrated that on average, strategic leadership has limited leverage on performance (Fitza, 2017; Hambrick \& Quigley, 2014). A possible explanation for these empirical gaps could be how strategic leadership and performance have been conceptualized and measured and the probable intermediate effects of the moderating and mediating variables. 
This paper thus argues that the external environment could be the moderating variable that limits the direct influence of strategic leadership on performance. The nature of the turbulent environment forces strategic leadership to articulate a clear vision of the future by implementing organizational change. This paper further argues that organizational change could be the mediating variable that influences the relationship between strategic leadership and performance.

\section{External Environmental}

The external environment is defined as any external force that plays a crucial role in influencing performance (Machuki \& Aosa, 2011). Dill (1958) defines it as a task environment consisting of external factors that directly constrain managerial behavior and organizational goals. It is the entire of all the physical and social factors external to the organization which are directly considered when managers are making decisions in the organization (Duncan, 1972). Bourgeois, (1980) posits that the external environment generally consists of various forces that can in the short term, significantly impact on the organization by creating distinct opportunities and threats for organizations. Bourgeois (1980) specifically points out that various scholars have defined it as an external object consisting of the general or task environment; or as an attribute in terms of complexity and dynamism; or as a managerial perception of the environmental uncertainty (Dill, 1958; Duncan, 1972; Lawrence \& Lorsch, 1967; Milliken, 1987; Tan \& Litschert 1994).

Prior literature indicates that there is no universal definition of the environment that is widely accepted, however, most scholars agree that the internal, external and the global environment are the most accepted forms (Hatch 1997). To narrow it down, many scholars point out that the contemporary support for the conceptualization or definition of the external environment is the task environment since it's considered the most relevant and pressing to the focal organization (Dill, 1958; Duncan, 1972; Tan \& Litschert, 1994; Castrogiovanni, 2002). This paper adopts the environment dependency theory (EDT) which builds upon the concept of the external environment

The external environment refers to the attributes, manifestations or the casual texture of the environment an organization faces as the focal unit of interest (Tung, 1979). When researchers' focus is on resource availability in the external environment, munificence is the primary concern (Castrogiovanni, 2002). Organizations operating in turbulent external environments face either scarcity or abundance of critical resources that can influence organizational performance (Dess \& Beard, 1984). When the focus is on the type of information uncertainties, dynamism and complexity are the primary variables (Castrogiovanni, 2002). When analyzing the degree, 
frequency and the rate of unpredictability of change among organizational elements, dynamism is the point of focus to strategic leadership (Tan \& Litschert, 1994). When investigating the scope, state and heterogeneity of environmental elements relevant to the focal organization, complexity becomes a critical dimension (Dess \& Beard, 1984). The importance of these three dimensions is evidenced by the many scholars who have investigated them albeit using different dimension labels (Machuki \& Aosa, 2011; Tan \& Litschert, 1994; Dess \& Beard, 1984).

In examining the influence of strategic leadership on performance, the effect of the external environment needs to be taken into account (Jansen et al 2009). While most empirical studies have explored and established a positive relationship between the external environment and performance (Tan \& Litschert, 1994), other studies have found an inverse or very minimal relationship (Van Dut, 2015). The inconclusive nature of the findings could suggest a bias towards studying the direct effect of the external environment on performance, while ignoring to link the relationship between strategic leadership and performance with the external environment moderating the relationship (House \& Aditya, 1977; Pawar \& Eastman, 1997). Bass (2007) observes that few studies have tested for such moderating effects. Therefore, this paper argues that rather than investigate the direct influence of strategic leadership on performance, such a relationship could be moderated by the external environment.

\section{Organizational Change}

Organizational change is of interest to scholars even though it has not been well defined due to its multifaceted nature (Kanter et al., (1992). However, scholars have defined it from different views ranging from individual to broad and to the systems perspectives. From an individual view, Van de Ven \& Poole, (1995) define it as the difference in form and quality over a period of time as an organization aligns with its external environment. Broadly, Cummings \& Worley, (2008) view it as a system of technical and managerial innovations as social organizations evolve and transform over a prolonged period of time. The systems component view sees it as a planned realignment of the entire system, influencing all the critical elements such as strategy, structures, people, and processes (Zhang \& Rajagopalan 2010).

Kezar (2001) suggests that when defining organizational change, the values and the perception of the organizational participant's should be examined. In support, Cao et al., (2000) opine that organizational change is a phenomenon more characterized by subjectivity rather than objectivity. Despite this lack of consensus in the definitions, Park \& Kim, (2015) see change as complex process of transforming the entire organization by focusing on the critical and interactive nature of the organizational components. 
Unfortunately, a critical review of the definitions on organizational change indicates different perspectives by various scholars and practitioners (Cao et al., 2000). This paper opines that since organizational change is a complex organizational wide transformational process it should be viewed in a holistic or systemic way. To reinforce this view, Cao et al., (2000) defines change as an approach incorporating diversity through interaction of critical organizational change components which includes process, structural, cultural, and political. This paper argues that rather than focus on the individual and the broader views that have been traditionally used to conceptualize change, the systems component view that focuses on the dimensions or elements of change of process, strategy, structure, culture, people and politics is to be used to complement each other within the intervention (Zhang \& Rajagopalan, 2013; Cao et al., 2003). This paper adopts the complexity theory which builds upon the construct of organizational change

Organizational change, whether it's continuous or discontinuous, large or small in scale and scope, rapid or slow, will determine the suitability of approaches to be used in organizational change. Most scholars agree that when analyzing organizational change, the focus should be on the rate or patterns of activities at the work place (Van de Ven \& Poole 1995; Weick \& Quinn 1999). Thus organizational change can be perceived differently based on how it has been analyzed (Cao et al., 2003). First, change has been classified by scholars as episodic, radical, first order, large scale, intentional, dramatic, strategic, bold stroke, systemic, formal and planned which implies it is infrequent and discontinuous (Kanter et al, 1992; Burnes, 2009). Secondly, other scholars have classified it as incremental, small scale, second order, long march, piecemeal, operational, reactive, informal and emergent which implies it is ongoing, evolving, cumulative, frequent and transformational. It's change driven by organizational unpredictability that requires quick responses to the global and local eventualities on a daily basis (Brown \& Eisenhardt, 1997; Reigeluth \& Garfinkle, 1994).

Organizational change can also be classified in terms of the business and people dimension (Hiatt, 2006). The business dimension involves change in strategy, business process systems, structure implementation and the post implementation phase. The people's dimension of change involves the alignment of the organizations' culture, values, beliefs and behavior that encourages desired results (Hiatt, 2006). Hiatt \& Creasey, (2012) argue that successful organizational change is when employees embrace the business dimension of change by being aware, have the desire, the knowledge, the requisite ability and the right behavior to reinforce (ADKAR) and implement those changes. Though scholars have categorized organizational change differently, the general consensus is that the planned and emergent approaches 
and the business and people dimensions of change are the acceptable frameworks in understanding the nature of organizational change (Hiatt \& Creasey, 2012; Burnes, 2004a).

Empirical literature on the relationship between organizational change and performance is inconclusive (Le \& Kroll, 2017; Kim \& McIntosh 2011, Wren \& Dulewicz, 2005). In some studies, organizational change improves performance (Zajac and Kraatz, 1993) while in other studies similar changes limit performance (Singh et al., 1986). Still other studies have either found no relationship or mixed relationships (Zajac and Shortell, 1989; Smith and Grimm, 1987). An organizational variable which is viewed as important in determining how organizational change enhances performance is strategic leadership (Zhang \& Rajagopalan, 2010; Virany et al, 1992). Scholars have also argued that the specific ways through which strategic leadership influence organizational change and performance are still under developed (Jansen et al., 2009).

Hence, most studies have failed to provide insights into the actual behaviors of strategic leadership and their failure to link them with organizational change and performance (Wren \& Dulewicz, 2005). Other possible explanations for these under researched empirical gaps may be in the ways strategic leadership, organizational change and performance are conceptualized and measured. Strategic leadership could affect the ability to engage in organization change, and therefore influence performance. Thus this paper contributes to this emergent dialogue and argues that the relationship between strategic leadership and performance could be mediated by organizational change.

\section{Organizational Performance}

There is an ongoing debate among scholars on how organizational performance (OP) can be conceptualized given its complexity and multidimensionality (Santos \& Brito 2012). Irrespective of the debate, the goal of OP is to create customer value through voluntary applications of productive assets provided by stakeholders (Carton, 2004). The concept of OP can be viewed narrowly as well as broadly. In a narrow sense, it refers to the financial, product market and shareholder return, while organizational effectiveness which is a broader concept includes both the financial indicators as well as the wider nonfinancial indicators such as, customer satisfaction, operations effectiveness and corporate social responsibility (Singh et al., 2016; Richard et al., 2009). It's also defined as a set of financial and non-financial constructs that enable strategic leadership to evaluate the extent of the accomplishment of organizational goals (Kaplan \& Norton, 1992; Venkatraman \& Ramanujam 1996). 
OP is also defined as a measure of how value is delivered to customers and other stakeholders as a result of how well organizations are managed (Carton, 2004). Ford \& Schellenberg (1982) summarized three major frameworks scholars have used to conceptualize OP based on customer and other stakeholder interests. The goal approach which is based upon explicit goals focuses on the behavior of organizational members as they attempt to accomplish them (Etzioni, 1964). The systems resource perspective by (Yuchtman \& Seashore, 1967) operationalizes OP in terms of evaluating key internal and external factors upon which organizational success is based on. Lastly, the constituency perspective views an organization as existing to create value and satisfy the needs of both internal and external constituencies (Cameron \& Quinn 2006).

A critical review of the empirical studies on the concept of OP indicates a bias towards achievement of financial goals and specifically on return on assets (ROA) or return on investment (ROI). This narrow definition limits its applicability since it's solely described in terms of a single operational measure. Thus organizations have to take cognizance of its various stakeholder interests and thus, organizational effectiveness becomes the appropriate way to define performance (Venkatraman and Ramanujam, 1986). Thus, this paper defines performance in terms of organizational effectiveness. This paper adopts the contingency and UET to build upon the construct of organizational performance

Studies on OP must accurately identify the available measures that operationalize it (Dess \& Robinson, 1984). Scholars have summarized various perspectives of OP measurement from three main research streams; management accounting, operations and strategic management respectively (Bititci et al., 2012). Generally, with regard to accounting measures, scholars have used objective and subjective measures (Chearskul, 2010). Objective measures include return on investment (ROI), return on assets (ROA), return on sales (ROS), and other market share based measures that are assumed to represent precise theoretical concepts of OP and they are universal in nature (Ketokivi \& Schroeder, 2004). No operational definition is attached to subjective measures and scholars can guide respondents on how performance manifests directly, either individually or in combination (Richard et al., 2008). When objective measures become unavailable, problematic and sensitive to access, some scholars have argued for the use of subjective measures (Dess \& Robinson 1984).

In retrospect, Kaplan and Norton (1992) recommend the use of the balanced scorecard (BSC) as it incorporates both management accounting, operational and strategic measures respectively. The BSC is thus able to capture information that is historical as well as expected future OP measures. 
They point out at the inevitability of integrating both the measures when assessing overall organizational performance.

Additionally, the concept of sustainability and the necessity for addressing sustainable development is a risk recognized by every contemporary organization in addressing key stakeholder concerns (Bititci et al, 2012). The use of multiple measures of performance referred to as the sustainable balanced score card (SBSC), incorporates both the financial and non financial measures that include society and environmental dimensions as a way of comprehensively addressing concerns of both the internal and external stakeholders and whose performance outcome is popularly referred to by scholars as the triple bottom line (TBL), (Porter \& Kramer, 2011; Elkington, 1994). However, the major limitation of TBL is that unlike the BSC measures, the environmental and social measures are difficult to quantify since they are unique to each organization or industry and thus cannot be aggregated into a single number (Hubbard, 2009). Scholars have also questioned the lack of clarity and consistency when measuring an organization's sustainability performance both from a conceptual, empirical and practical perspective (Sridhar \& Jones, 2013).

Empirical studies have demonstrated that strategic leadership is an important determinant of organizational performance (Witts, 2016; Lord, et al., 2016). However, other studies assert that strategic leadership is an inconsequential determinant of performance because of various constraints they face or due to some randomness or chance effects (Fitza, 2017; Quigley \& Hambrick, 2015; Day \& Lord, 1988). A further explanation of these empirical gaps could be how the constructs of strategic leadership is operationalized and measured and the difficulty in identifying a way of integrating the complex and multi dimensionality nature of performance. This paper in a bid to address both the conceptual and empirical gaps, proposes for the adoption of the balanced score card (BSC) approach in measuring performance and further advances an argument that the influence of strategic leadership on performance is tenuous as the external environment and organizational change could moderate and mediate the relationship respectively.

\section{Strategic Leadership and Performance}

Scholars have argued that top managers have sufficient discretion and strategic choices to influence performance (Crossland \& Hambrick, 2011). Thus the role of CEOs in influencing their organizations' performance through their behaviors and strategic choices is critical (Quigley \& Hambrick, 2015). However, other scholars have recognized that constraints can limit strategic leadership from gaining total control in influencing their organizations' performance (Lieberson \& O’Connor 1972). 
The inconsistent findings of these studies could be due to the exclusion of critical organizational and environmental variables that could either moderate or mediate the relationship (House \& Aditya, 1997). Methodological difficulties of prior studies have also contributed to the strategic leadership and performance debate. This paper addresses these knowledge gaps and argues that the effect of strategic leadership on performance is indirect since it could be moderated and mediated by the external environment and organizational change respectively.

\section{Strategic Leadership, External Environment and Performance}

Many empirical studies have demonstrated that the influence of strategic leadership is critical to organisational performance (Quigley \& Graffin, 2017). Similarly, strategic leadership will be most effective during environmental uncertainties (Jansen et al., 2009). Unfortunately, other studies have found out that such an influence is paradoxical since the complex nature of the external environment and other contextual factors may likely constraint or limit the CEO effect (Fitza, 2017). Thus, as pointed out by Waldman et al., (2001), the effectiveness of strategic leadership on performance will vary given the level of environmental turbulence.

This leads to the suggestion that the external environment is a critical variable in influencing the relationship between strategic leadership and performance. In a bid to address this gap in knowledge, this paper argues that rather than investigate the causal relationship between strategic leadership and organizational performance, the external environment could have a moderating influence.

\section{Strategic Leadership, Organizational Change and Performance}

The various choices made by an organization's strategic leadership as they engage in organizational change have a profound influence on performance (Kotter, 1996; Burke \& Litwin 1992). Empirical studies have demonstrated that effective strategic leadership is at the core of creating a sustainable competitive advantage in rapidly changing organizations (Gilley, 2005). Strategic leadership must therefore articulate a clear vision of the future organization in order to successfully implement organizational change and hence long term performance. Extant empirical knowledge on the relationship between strategic leadership, organizational change and performance indicate no consistent findings, while other studies show that different types of strategic leadership behaviors are associated with various organizational changes and performance levels (Battilana et al., 2010). Other scholars argue that when organizational change is hastily implemented, performance can be negatively affected (Kim \& McIntosh, 2011). 
This lack of consistency could be attributed to differences in the definitions of the three variables of strategic leadership, organizational change and performance, the study context or the role of strategic leadership and how it can be conclusively linked to organizational change and performance (Herold et al 2008). In addition, the role played by organizational change must be considered in addressing the inconclusive findings of prior studies. Hence, in filling these knowledge gaps, this paper argues that organizational change could have a mediating effect on the relationship between strategic leadership and performance.

\section{Strategic Leadership, External Environment, Organizational Change and Performance}

Scholars has conceptualized and empirically determined the influence of strategic leadership on performance (Fitza, 2017; Ireland \& Hitt, 1999). However, Knies et al (2016) point out that this casual relationship is questionable since other studies have demonstrated that their influence on performance may be limited due to contextual constraints. These disparate findings indicate either a lack of evidence in establishing a direct association between the broad conceptualization of strategic leadership and performance or of the many confounding variables that make it difficult to demonstrate clear cause and effect (Quigley \& Graffin, 2017; Knies et al., 2016).

To address this knowledge gap, this paper argues that strategic leadership influences performance but not directly, since the external environment could have a moderating effect on the relationship. Due to the uncertainty of the external environment, an organization's strategic leadership must also make changes in their operational and strategic directions in order to stay relevant and improve performance (Kraatz \& Zajac, 2001). This suggests that organizational change could have a mediating effect on the relationship between strategic leadership and performance.

\section{Summary of Knowledge Gaps}

A review of the empirical literature presents mixed findings on the impact or how much of the variance in performance could be causally linked to strategic leadership. This has been attributed to various reasons such as the different methodologies used, conceptualization of the variables under the study and more importantly, contextual factors. Additionally, performance differentials in the empirical literature could be as a result of the influence of the external environment on the causal relationship between strategic leadership and performance. Thus the external environment could have a moderating influence on the envisaged relationship.

Empirical findings on the effect of strategic leadership and organizational change on performance are equivocal. This lack of consistency could be due 
to differences in the definitions of the constructs, the role played by strategic leadership and the mediating influence of organizational change on performance. In addition, since performance is a multidimensional construct, how it's conceptualized and measured makes it difficult for scholars to agree on the casual link between strategic leadership and performance.

Accordingly, various studies reviewed have not explicitly tested the joint relationship between strategic leadership, external environment and organizational change on organizational performance. In a bid to address the knowledge gap, this paper argues that the influence of strategic leadership on performance could be limited due to the moderating influence of the external environment and the mediating role of organization change. Table 1 presents a summary of different studies and the gaps which inform the emerging propositions. The knowledge gaps need to be addressed by way of empirical research.

Table 1: Summary of Knowledge Gaps

\begin{tabular}{|c|c|c|c|c|}
\hline & Researcher & Focus & Findings & Knowledge Gap Areas \\
\hline 1 & $\begin{array}{l}\text { Fitza, } \\
(2017)\end{array}$ & $\begin{array}{l}\text { An empirical test of } \\
\text { Quigley \& Graffin's } \\
\text { (2017) framework on } \\
\text { how much of the } \\
\text { variance in } \\
\text { performance can be } \\
\text { attributed to CEOs }\end{array}$ & $\begin{array}{l}\text { The analysis and results } \\
\text { show that the influence } \\
\text { of CEOs on performance } \\
\text { is not significant since } \\
\text { they are mainly } \\
\text { constrained by chance or } \\
\text { random events. This } \\
\text { contradicts Quigley \& } \\
\text { Graffin's (2017) results } \\
\text { that CEOs have a } \\
\text { significant effect on } \\
\text { performance }\end{array}$ & $\begin{array}{l}\text { The study did not investigate the } \\
\text { effect of strategic leadership on } \\
\text { performance by explicitly } \\
\text { incorporating the external } \\
\text { environment and organizational } \\
\text { change as moderating and mediating } \\
\text { variables respectively }\end{array}$ \\
\hline 2 & $\begin{array}{l}\text { Quigley \& } \\
\text { Graffin, (2017). }\end{array}$ & $\begin{array}{l}\text { A replication of } \\
\text { Fitza's (2014) study } \\
\text { using multi - level } \\
\text { modeling, which is a } \\
\text { more appropriate } \\
\text { statistical technique } \\
\text { than the ANOVA } \\
\text { model Fitza used }\end{array}$ & $\begin{array}{l}\text { Their findings contrast } \\
\text { with Fitza's (2014) } \\
\text { where they were able to } \\
\text { demonstrate the positive } \\
\text { impact of CEOs on } \\
\text { performance }\end{array}$ & $\begin{array}{l}\text { The study did not address the indirect } \\
\text { influence of strategic leadership on } \\
\text { performance and explicitly } \\
\text { incorporate constraining factors of the } \\
\text { external environment as a moderating } \\
\text { variable and organizational change as } \\
\text { a mediating variable. It did not also } \\
\text { use a multiple regression model to } \\
\text { analyze and measure the joint effect } \\
\text { of the variables }\end{array}$ \\
\hline 3 & $\begin{array}{l}\text { Kitonga, D. K, } \\
(2017)\end{array}$ & $\begin{array}{l}\text { The influence of } \\
\text { strategic leadership } \\
\text { practices on } \\
\text { performance in not } \\
\text { for profit } \\
\text { organizations in } \\
\text { Nairobi County, } \\
\text { kenya }\end{array}$ & $\begin{array}{l}\text { The analysis and results } \\
\text { show a significant } \\
\text { positive correlation } \\
\text { between strategic } \\
\text { leadership practices and } \\
\text { performance }\end{array}$ & $\begin{array}{l}\text { The study focused on the direct } \\
\text { relationship between strategic } \\
\text { leadership practices and performance } \\
\text { without incorporating the influence of } \\
\text { the external environment and } \\
\text { organizational change as moderating } \\
\text { and mediating variables respectively. }\end{array}$ \\
\hline 4 & $\begin{array}{l}\text { Knies et al, } \\
\text { (2016) }\end{array}$ & $\begin{array}{lc}\text { The influence } & \text { of } \\
\text { Leadership } & \text { on } \\
\text { Performance in } & \text { in } \\
\text { public organizations }\end{array}$ & $\begin{array}{l}\text { The analysis and results } \\
\text { support the propositions } \\
\text { that Transformational } \\
\text { and Transactional } \\
\text { leadership styles have a } \\
\text { positive impact on } \\
\text { performance, although } \\
\text { size effect varies } \\
\text { considerably. }\end{array}$ & $\begin{array}{l}\text { The study focused on the influence of } \\
\text { leadership on performance from a } \\
\text { micro level perspective and not the } \\
\text { macro level perspective of strategic } \\
\text { leadership and how it could influence } \\
\text { performance through the balanced } \\
\text { score card (BSC) }\end{array}$ \\
\hline
\end{tabular}




\begin{tabular}{|c|c|c|c|c|}
\hline 5 & $\begin{array}{l}\text { Witts, J. O., } \\
(2016)\end{array}$ & $\begin{array}{l}\text { The Role of Strategic } \\
\text { Leadership in } \\
\text { enhancing } \\
\text { Profitability }\end{array}$ & $\begin{array}{l}\text { Strategic leadership skills } \\
\text { significantly influence } \\
\text { profitability. }\end{array}$ & $\begin{array}{l}\text { The study assumed a linear } \\
\text { relationship between strategic } \\
\text { leadership and performance without } \\
\text { considering constraining factors such } \\
\text { as the external environment and } \\
\text { organizational change as moderating } \\
\text { and mediating variables respectively }\end{array}$ \\
\hline 6 & $\begin{array}{l}\text { Mutia, } \\
\text { (2015) }\end{array}$ & $\begin{array}{l}\text { Strategic Leadership } \\
\text { and its Influence on } \\
\text { Church Growth in } \\
\text { Kenya }\end{array}$ & $\begin{array}{l}\text { There is a significant } \\
\text { positive relationship } \\
\text { between } \\
\text { leadership practices and } \\
\text { organizational growth }\end{array}$ & $\begin{array}{l}\text { The study did not investigate the } \\
\text { indirect influence of strategic } \\
\text { leadership practices on organizational } \\
\text { growth as it did not include the } \\
\text { moderating and mediating roles of the } \\
\text { external environment and } \\
\text { organizational change }\end{array}$ \\
\hline 7 & Fitza, (2014) & $\begin{array}{l}\text { An empirical study } \\
\text { to investigate how } \\
\text { randomness can } \\
\text { affect the measured } \\
\text { effects in a variance } \\
\text { decomposition } \\
\text { analysis with a focus } \\
\text { on the measuring the } \\
\text { CEO effect }\end{array}$ & $\begin{array}{l}\text { The CEO effect on } \\
\text { performance is not } \\
\text { significant as it is mostly } \\
\text { influenced by chance } \\
\text { effects or random events. }\end{array}$ & $\begin{array}{l}\text { The study did not incorporate the } \\
\text { moderating and mediating variables of } \\
\text { the external environment and } \\
\text { organization change in the } \\
\text { relationship between strategic } \\
\text { leadership and performance. } \\
\text { Performance measures were also } \\
\text { replaced by some random variable } \\
\text { rather than the use of an objective } \\
\text { performance measure such as the } \\
\text { balanced score card }\end{array}$ \\
\hline 8 & Mackey (2008) & $\begin{array}{l}\text { The effect of CEOs } \\
\text { in certain settings on } \\
\text { firm performance }\end{array}$ & $\begin{array}{l}\text { In certain settings the } \\
\text { effect of CEOs on } \\
\text { corporate performance is } \\
\text { significant than that of } \\
\text { industry and firm effects }\end{array}$ & $\begin{array}{l}\text { The study did not consider the task } \\
\text { environment as a key moderating } \\
\text { variable in determining the } \\
\text { relationship between strategic } \\
\text { leadership and corporate performance }\end{array}$ \\
\hline 9 & \begin{tabular}{l}
\multicolumn{1}{c}{ Goll, } \\
Johnson \& \\
Rasheed (2007)
\end{tabular} & $\begin{array}{l}\text { Knowledge } \\
\text { Capability, Strategic } \\
\text { Change and Firm } \\
\text { Performance. The } \\
\text { External } \\
\text { Environment as a } \\
\text { Moderating Variable }\end{array}$ & $\begin{array}{l}\text { Knowledge capability of } \\
\text { strategic leaders } \\
\text { significantly influences } \\
\text { performance although the } \\
\text { relationship is moderated } \\
\text { by the external } \\
\text { environment and } \\
\text { mediated by strategic } \\
\text { change }\end{array}$ & $\begin{array}{l}\text { The study used demographic } \\
\text { characteristics as proxy variables of } \\
\text { strategic leadership instead of the } \\
\text { broader construct of strategic } \\
\text { leadership practices }\end{array}$ \\
\hline 10 & $\begin{array}{l}\text { Hambrick \& } \\
\text { Mason (1984) }\end{array}$ & $\begin{array}{l}\text { The composition of } \\
\text { an organization's top } \\
\text { managers and their } \\
\text { influence on } \\
\text { performance }\end{array}$ & $\begin{array}{l}\text { Organizational } \\
\text { performance levels-are } \\
\text { partially predicted by } \\
\text { managerial background } \\
\text { characteristics. } \\
\text { significant influence on } \\
\text { Performance } \\
\end{array}$ & $\begin{array}{l}\text { The study employed demographic } \\
\text { proxy variables instead of the external } \\
\text { environment as moderating variables } \\
\text { in investigating the influence of } \\
\text { strategic leadership on performance. }\end{array}$ \\
\hline 11 & $\begin{array}{c}\text { Salancik \& } \\
\text { Pfeffer (1977) }\end{array}$ & $\begin{array}{l}\text { Constraints that } \\
\text { limit managerial } \\
\text { discretion }\end{array}$ & $\begin{array}{c}\text { The influence of } \\
\text { leadership on } \\
\text { performance is } \\
\text { significantly limited by } \\
\text { internal structure, } \\
\text { procedural factors and } \\
\text { external demands on the } \\
\text { organization } \\
\end{array}$ & $\begin{array}{l}\text { The study did not address the total } \\
\text { amount of performance variance } \\
\text { attributed to strategic leadership }\end{array}$ \\
\hline 12 & $\begin{array}{l}\text { Lieberson \& } \\
\text { O'Connor (1972) }\end{array}$ & $\begin{array}{l}\text { The influence of } \\
\text { leadership and } \\
\text { performance in large } \\
\text { corporations in } \\
\text { America }\end{array}$ & $\begin{array}{l}\text { The influence of } \\
\text { leadership on } \\
\text { performance is limited as } \\
\text { only } 6.5 \% \text { of the } \\
\text { variance of performance } \\
\text { is explained by the } \\
\text { leadership effect }\end{array}$ & $\begin{array}{l}\text { The study did not focus on the } \\
\text { influence of the strategic leadership } \\
\text { construct on performance by using the } \\
\text { balance score card measures }\end{array}$ \\
\hline
\end{tabular}




\section{Emerging Propositions and Areas for Further Research}

Several propositions have emerged from the reviewed literature. Many scholars who subscribe to the leadership school argue that the influence of strategic leadership on performance is substantial (Hambrick \& Quigley, 2014). However, others who endorse the constraint school argue that such an influence is limited by contextual factors (Knies et al., 2016). Thus, the question of whether strategic leadership influences performance is yet to be resolved given the findings as evidenced by the recent scholarly debate (Quigley \& Graffin, 2017; Fitza, 2014; 2017). However, most contemporary studies using improved methodologies have generally found a positive relationship between strategic leadership and performance. Thus:

Proposition 1: Strategic Leadership could be positively related to organizational performance

Strategic leadership plays a major role in determining performance by enabling their organizations cope with their external environment (Jansen et al., 2009). Unfortunately, other studies have found out that such an influence is paradoxical since the complex nature of the external environment may likely constraint or limit the CEO effect (Fitza, 2017). Conger (1999) further points out that there is scarcity of empirical studies focusing on the moderating role of the external environment in the relationship between strategic leadership and performance. Generally, empirical studies have demonstrated that the external environment is a critical moderating variable that determines the relationship between strategic leadership and performance (Jansen et al, 2009; Goll et al., 2007). Thus:

Proposition 2: The external environment could moderate the relationship between strategic leadership and performance.

Studies have shown that strategic leadership influences organization change and ultimately performance given that they need to articulate a clear vision of the future organization (Goll et al., 2007). However, other scholars argue that when change is hastily implemented, performance can be negatively affected or the relationship is not consistent (Kim \& McIntosh, 2011; Battilana et al., 2010). Generally, studies show that strategic leadership leads to organization change and which in turn influences performance (Gilley et al., 2009; Goll et al., 2007). Thus:

Proposition 3: Organizational change could mediate the relationship between strategic Leadership and performance.

The influence of strategic leadership on performance has generally been agreed upon by most scholars while others point to its limited influence due to contextual constraints (Quigley \& Graffin, 2017; Fitza, 2017). These inconsistent findings suggest either a lack of evidence in establishing a direct association between strategic leadership and performance or of the many 
confounding variables that make it difficult to demonstrate clear cause and effect (Knies et al., 2016). Thus

Proposition 4: The influence of strategic leadership on performance could be moderated by the external environment and mediated by organizational change.

\section{Conclusion}

This paper has revealed various knowledge gaps revolving around the relationship between strategic leadership, the external environment, organizational change and performance. Studies have beeen inconclusive when examining the effect and extent of strategic leadership on performance. Although evidence shows that the strategic leadership actions substantially influence performance, the processes through which they exert this influence is still limited and largely speculative. Thus, the presence of strategic leadership however, does not merely lead to high performance since other antecedents may be at play. Few empirical studies have systematically traced the causal path of the effects of strategic leadership on performance by examining the moderating and mediating influence of the external environment and organizational change respectively. This paper seeks to address this research gap by arguing that the external environment and organizational change could influence the relationship between strategic leadership and organizational performance.

Thus, the external environment in which an organization is anchored in could have a significant moderating influence on the relationship between strategic leadership and performance. In equal measure, organizations facing the realities of external environment could improve their chances of success by engaging in organizational change. Thus, the relationship between strategic leadership and performance could be influenced by the mediating role of organizational change. This paper therefore concludes that strategic leadership indirectly influences performance since the external environment and organizational change could moderate and mediate respectively the relationship between strategic leadership and performance. The paper proposes that strategic leadership is the independent variable while performance as the dependent variable.

\section{References:}

1. Allio, R. J. (2013). Leaders and leadership - Many theories but what advice is reliable? Strategy \& Leadership, 41 (1), 4 - 14. doi:10.1106/10878571311290016

2. Ansoff, H. I., \& Sullivan, P. A. (1993). Optimizing Profitability in Turbulent Environments : A Formula for Strategic Success. Long Range Planning, 26 (5), 11 - 23 
3. Bass, B. M. (1985). Leadership and Performance Beyond Expectations. New York: Free Press

4. Bass, B. M. (2007). Executive and Strategic Leadership. International Journal of Business, 12(1), 33 - 52

5. Bititci, U. P., Garengo, V. D., \& Nudurupati, S. (2012). Performance Measurement: Challenges for Tomorrow. International Journal of Management Reviews, 14 (3), 305-327.

6. Blettner, P.B., Chaddad, F. N., \& Bettis, R. A. (2012). The CEO performance effect: Statistical issues and a complex fit perspective. Strategic Management Journal, 33 (1): 986-999.

7. Boal, K. B., \& Hooijberg, R. (2001). Strategic Leadership Research: Moving On. Leadership Quarterly, 11 (4), 515 - 549

8. Bonardi, J.P., Hitt, M. A., Vera, D., \& Withers, M. C. (2018). Special Issue on Strategic Leadership and Strategic Management. The Leadership Quarterly, 29 (1), VII - VIII

9. Bourgeois, L. J. III. (1980). Strategy and Environment: A Conceptual Integration. Academy of Management Review, 5 (1), 25-39

10. Brown, S. L., \& Eisenhardt, K. M. (1997). The Art of Continuous Change: Linking Complexity Theory and Time-Paced Evolution in Relentlessly Shifting Organizations. Administrative Science Quarterly, 42 (1), 1-34

11. Burke, W. W., \& Litwin, G. H. (1992). A Causal Model of Organizational Performance and Change. Journal of Management, $18(3), 523-545$

12. Burnes, B. (2004a). Kurt Lewin and the Planned Approach to Change: A Reappraisal. International Journal of Operations and Production Management, 24 (9), 886 - 902

13. Burnes, B. (2005).Complexity Theories and Organizational Change. International Journal of Management Reviews, 7(2), 73-90.

14. Burnes, B. (2009). Managing Change: A Strategic Approach to Organizational Dynamics, $5^{\text {th }}$ Edition Prentice Hall

15. Cameron, K. S., \& Quinn, R. E. (2006). Diagnosing and Changing Organizational Culture: Based on the Competing Values Framework (Revised Ed.). San Francisco, CA: Jossey-Bass.

16. Cao, G., Clarke, S., Lehaney, B. (2000). A Systemic View of Organizational Change and TQM. The TQM Magazine, 12 (3), 186193

17. Cao, G., Clarke, S., and Lehaney, B. (2003). Diversity Management: Towards a Systemic Framework. Systems Research Behavioral Science, 20(3), 231-242. 
18. Carter, S. M., \& Greer, C. R. (2013). Strategic Leadership: Values, Styles, and Organizational Performance. Journal of Leadership \& Organizational Studies, 20 (4), 375 -393

19. Carton, R. B. (2004). Measuring Organizational Performance: An Exploratory Study. (Unpublished Doctoral Thesis). University of Georgia, Athens, Georgia

20. Castelli, P. N. (2016). Reflective Leadership Review: A Framework for Improving Organisational Performance. Journal of Management Development, 35 (2), 217- 236

21. Castrogiovanni, G. J. (2002). Organization Task Environments: Have they Changed Fundamentally over Time? Journal of Management, 28 (2), 129-150

22. Chearskul, P. (2010). An Empirical Investigation of Performance Measurement System Use and Organizational Performance. (Unpublished Doctoral Thesis). Virginia Polytechnic Institute and State University

23. Crossan, M., Vera, D., \& Nanjad, L.(2008). Transcendent Leadership: Strategic Leadership in Dynamic Environments. Leadership Quarterly, 19 (5), 569 - 581

24. Crossland, C., \& Hambrick, D. C.(2010). Differences in Managerial Discretion Across Countries: How Nation-Level Institutions Affect The Degree To Which Ceos Matter. Strategic Management Journal, 32 (8), 797-819

25. Cummings, T. G., \& Worley, C. G.(2008). Organization Development $\&$ Change, $9^{\text {th }}$ Ed. Mason, OH: South-Western College Publishing.

26. Dess, G. G., \& Beard, D. W. (1984). Dimensions of Organizational Task Environments. Administrative Science Quarterly, 29 (1), 52-73.

27. Dess, G. G., \& Robinson, R. B. (1984). Measuring Organizational Performance in the Absence of Objective Measures: The Case of the Privately - held Firm and Conglomerate Business Unit. Strategic Management Journal, 5 (3), 265-279.

28. De Jong, G., Phan, A. T. \& Van Ees, H.(2012). Which Entrepreneurs Bribe and What do they get from it? Exploratory Evidence from Vietnam. Entrepreneurship Theory and Practice, 36 (2), 323-345.

29. Dill, W. R.(1958). Environment as an Influence on Managerial Autonomy. Administrative Science Quarterly , 2 (4), 409-443

30. Donaldson, L.(2001). The Contingency Theory of Organizations. Thousand Oaks, California, Sage Publications, Inc

31. Duncan, R. B.(1972), Characteristics of Organizational Environments and Perceived Environmental Uncertainty. Administrative Science Quarterly, 17 (2), 313 - 327 
32. Elkington, J.(1997). Cannibals With Forks: The Triple Bottom Line of 21st Century Business. Capstone: Oxford.

33. Etzioni, A.(1964). Modern Organizations. Prentice-Hall, Englewood Cliffs.

34. Fitza, M.(2014). The Use of Variance Decomposition in the Investigation of CEO Effects: How Large Must the CEO Effect be to Rule Out Chance? Strategic Management Journal, 35 (12), 18391852

35. Fitza, M.(2017). How Much Do Ceos Really Matter? Reaffirming That the Ceo Effect is Mostly Due to Chance. Strategic Management Journal, 38 (3), 802-811

36. Ford, J. D., \& Ford, L. W.(2012). The Leadership of Organization Change: A View from Recent Empirical Evidence. Research in Organizational Change and Development, 20, 1-36

37. Ford, J. D. \& Schellenberg, D. A.(2005). Conceptual Issues of Linkage in the Assessment of Organizational Performance. Academy of Management Review, $7 \quad$ (1), 49-58.

38. Gilley, A.(2005). The Manager as Change Leader. Westport, CT, Praeger.

39. Gilley, A., Heather, S., \& Gilley, J. W.(2009). Organizational Change and Characteristics of Leadership Effectiveness. Journal of Leadership \& Organizational Studies. 16 (1), 38 - 47

40. Ginsberg, A., \& Venkatraman. N.(1985). Contingency Perspectives of Organizational Strategy: A Critical Review of the Empirical Research. Academy of Management Review,10 (3), 421-434.

41. Goll, I., Johnson, N. B., \& Rasheed, A. A. (2007). Knowledge Capability, Strategic Change, and Firm Performance: The Moderating Role of the Environment, Management Decision, 45 (2), 161 - 179

42. Hagen, A. F., Hassan, M. T., \& Amin, S. G.(1998). Critical Strategic Leadership Components: An Emprical Investigation. Advanced Management Journal, 63 (3), 39 - 44

43. Hambrick, D. C., \& Mason, P. A.(1984). Upper Echelons: The Organization as a Reflection of Its Top Managers. The Academy of Management Review, 9 (2), 193- 206

44. Hambrick, D. C., \& Quigley, T. J.(2014). Toward more Accurate Contextualization of the Ceo Effect on Firm Performance. Strategic Management Journal, 35 (4), 473- 491

45. Hatch, M. J.(1997). Organization Theory: Modern, Symbolic and Postmodern Perspectives. Oxford: Oxford University Press.

46. Haveman, H. A.(1992). Between a Rock and a Hard Place: Organizational Change and Performance under Conditions of 
Fundamental Environmental Transformation. Administrative Science Quarterly, 37 (1), 48-75.

47. Herold, D. M., Fedor, D. B., Caldwell, S., \& Liu, Y.(2008). The Effects of Transformational and Change Leadership on Employee Commitment to Change: A Multilevel Study. Journal of Applied Psychology, 93(2), 346-357.

48. Hiatt, J. M. (2006). ADKAR: A Model For Change in Business, Government and Our Community. Prosci Learning Center.

49. Hiatt, J. M., \& Creasey, J. T.(2012). Change Management: The People Side of Change, 2nd Edition, Loveland, Colorado, USA. Prosci Inc

50. Higgs, M., \& Rowland, D.(2005). All Changes Great and Small: Exploring Approaches to Change and its Leadership. Journal of Change Management, 5(2), 121-151.

51. Hitt, M. A., Ireland, R. D., \& Hoskisson, R. E.(1995). Strategic Management: Competitiveness and Globalization - Concepts, $1 \mathrm{st}$ Edition, West Publishing Company

52. House, R. J., \& Aditya, R. N.(1997). The Social Scientific Study of Leadership: Quo Vadis? Journal of Management, 23 (3), 409 - 473

53. Hubbard, G. (2009). Measuring Organizational Performance: Beyond the Triple Bottom Line. Business Strategy and the Environment, 18 (3), 177-191.

54. Ireland, R. D., \& Hitt, M. A.(1999). Achieving and Maintaining Strategic Competitiveness in the 21st century: The Role of Strategic Leadership. Academy of Management Executive, 13 (1), 63 - 72

55. Jansen, J. J. P., Vera, D. \& Crossan, M. (2009). Strategic Leadership for Exploration and Exploitation: The Moderating Role of Environmental Dynamism, The Leadership Quarterly, 20 (1), 5-18.

56. Jouste, C., \& Fourie, B.(2009). The Role of Strategic Leadership in Effective Strategy Implementation: Perceptions of South African Strategic Leaders. Southern African Business Review,13 (3), 51 - 68

57. Kanter, R. M., Stein, B. A., \& Jick, T. D.(1992). The Challenge of Organizational Change. New York, USA, Free Press

58. Kaplan, R. S., \& Norton, D. P.(1992). The Balanced Scorecard Measures that Drive Performance. Harvard Business Review, 70 (1), 71-79.

59. Ketokivi, M. A., \& Schroeder, R. G. (2004). Perceptual Measures of Performance: Fact or Fiction? Journal of Operations Management, 22(3), 247-264.

60. Kezar, A.J.(2001). Understanding and Facilitating Organizational Change in the 21st Century: Recent Research and Conceptualizations, ASHE-ERIC Higher Education Report, 28 (4), 1 
61. Kim J. S., Kang, S. A., \& Park, H. J.(2014). Impact of CEO Leadership Styles on Firm Performance During Environmental Uncertainty. A Study of Privately Owned Korean Companies. Research Journal of Business Management, 8 (1), 43 - 44

62. Kim, E., \& Mc Intosh, J. C.(2011). The Faster, the Better?: An Empirical Study on the Speed of Strategic Change and Firm Survival and Performance. Journal of Applied Business Research, 12 (2), 35 - 40

63. Kitonga, D. M. (2017). Strategic Leadership Practices and Organizational Performance in Not-For-Profit Organizations in Nairobi County in Kenya. (Unpublished Doctoral Thesis). Jomo Kenyatta University of Agriculture and Technology, Kenya

64. Knies, E.; Jacobsen, C. \& Tummers, L.G. (2016). Leadership and Organizational Performance: State of the Art and Research Agenda. In: Storey, J., Denis, J.L., Hartley, J. \& Hart, P. (Eds.). Routledge Companion to Leadership (pp. 404-418). London: Routledge.

65. Kotter, J. P.(1996). Leading Change. Boston, MA, USA, Harvard Business School Press

66. Lawrence, P.R., \& Lorsch, J.W.(1967). Organizationand Environment:Managing Differentiation and Integration. Boston, MA: Harvard University.

67. Le, S., \& Kroll, M.(2017). CEO International Experience: Effects on Strategic Change and Firm Performance. Journal of International Business Studies, Vol. 48 (5), $573 \quad-595$

68. Lieberson, S., \& O’Connor, F.(1972). Leadership and Organizational Performance: A Study of Large Corporations. American Sociological Review, 37 (2), 117 - 130

69. Lord, R. G, Devlin, S. H, Caldwell, C. O, \& Kass, D.(2016). Leadership in the National Football League: Do Leaders Make a Difference? In Leadership Lessons from Compelling Contexts. Monographs in Leadership and Management, 8, 29 - 66

70. Machuki, V. N., \& Aosa, E.(2011). The Influence of the External External Environment on the Performance of Publicly Quoted Companies in Kenya. Prime Journal of Business Administration and Management, 1 (7), $205-218$

71. Meindl, J.R., \& Ehrlich, S, B. (1987). The Romance of Leadership and the Evaluation of Organizational Performance. Academy of Management Journal, 30 (1), 91 - 109

72. Milliken, F. (1987). Three Types of Perceived Uncertainty about the Environment: State, Effect, and Response Uncertainty. The Academy of Management Review, 12 (1), $\quad 133-143$ 
73. Garc1'a-Morales, V. J., Llore'ns-Montes, F.J., \& Verdu' -Jover, A. J. (2008). The Effects of Transformational Leadership on Organizational Performance through Knowledge and Innovation. British Journal of Management, 19, 299-319 (2008)

74. Mutia, P. M.(2015). Strategic Leadership and its Influence on Church Growth in Kenya. (Unpublished Doctoral Thesis). Chandaria School of Business. United States International University - Africa

75. Neneh, B. N., \& Vanzyl, J. (2014). Growth Intention and Its Impact on Business Growth Amongst SMEs in South Africa. Mediterranean, Journal of Social Sciences, 5(20), 172-183.

76. North, D.C.(1991). Institutions. Journal of Economic Perspectives, 5 (1), 97-112.

77. Osborn, R. N., \& Hunt, J. G.(1974). Environment and Organizational Effectiveness. Administrative. Science Quarterly, 19 (2), 231- 246

78. Park, S., \& Kim, E.(2015). Revisiting Knowledge Sharing from the Organizational Change Perspective. European Journal of Training and Development, 39 (9), $769 \quad-797$

79. Pearce, J. I., \& Robinson, B. R. (2012). Strategic Management: Formulation, Implementation and Control, 13th ed. Boston: Irwin McGraw-Hill.

80. Quinn, J. B.(1982). Managing Strategies Incrementally. Omega, 10 (16), $613-27$

81. Quigley, T. J., \& Graffin, S.D.(2017). Reaffirming the CEO effect is significant and much larger than chance: A comment on Fitza (2014). Strategic Management Journal, 38 (3), 793- 801.

82. Quigley, T. J., \& Hambrick, D. C.(2015). Has the "Ceo Effect" Increased in Recent Decades? A New Explanation For The Great Rise in America's Attention To Corporate Leaders. Strategic Management Journal, 36 (6), 821-830

83. Reigeluth, C. M., \& Garfinkle, R. J.(1994). Systemic Change in Education. New Jersey: Educational Technology Publications Englewood Cliffs

84. Richard, P. J., Devinney, T. M., Yip, G. S., \& Johnson, G.(2009). Measuring Organizational Performance: Towards Methodological Best Practice. Journal of Management, 35 (3) , 718-804

85. Romanelli, E., \& Tushman, M. L.(1994). Organizational Transformation as Punctuated Equilibrium: An Empirical Test. Academy of Management Journal, 37 (5), 1141 - 66

86. Rowe, G., \& Nejad, M.H., (2009). Strategic Leadership: Short- Term Stability and Long Term Viability. Ivey Business Journal, 73(5), 6-11. 
87. Salanick, G.R., \& Pfeffer, J., (1977). Constraints on Administrator Discretion: The Limited Influence of Mayors. Urban Affairs Quarterly, 12 (4)

88. Santos, J. B., \& Brito, L. A. L.(2012). Toward a Subjective Measurement Model for Firm Performance, Brazilian Administrative Review, 9 (6), 95-117

89. Serfontein, K., \& Hough, J.(2011). Nature of the Relationship between Strategic Leadership, Operational Strategy and Organizational Performance. South African Journal of Economic and Management Sciences, 14 (4), 393 - 406

90. Scott, R.W. (2005). Institutional theory: Contributing to a Theoretical Research Program. In K.G. Smith \& M.A. Hitt, Great Minds in Management: The Process of Theory Development, 460-84, Oxford: Oxford University Press.

91. Shoemaker, P. J. H., Krupp, S., \& Howland, S. (2013). Strategic Leadership: The Essential Skills. Harvard Business Review, 91 (1 2), $131-134$

92. Singh, S., Darwish, T. K., \& Potocnik, K.(2016). Measuring Organizational Performance: A Case for Subjective Measures, British Journal of Management, 27 (1), 214-224

93. Sridhar, K., \& Jones, G. (2013). The Three Fundamental Criticisms of the Triple Bottom Line approach: An Empirical Study to Link Sustainability Reports in Companies Based in the Asia-Pacific Region and TBL Shortcomings. Asian Journal of Business Ethics, 2 (1), 91 111

94. Stacey, R. D., Griffin, D., \& Shaw, P.(2002). Complexity and Management: Fad or Radical Challenge to Systems Thinking. London, Routledge

95. Strand, R. (2014). Strategic Leadership of Corporate Sustainability, Journal of Business Ethics, 123 (4), 687-706

96. Tan, J. J., \& Litschert, R. J. (1994). Environment - Strategy Relationship and its Implications: An Empirical Study of the Chinese Electronics Industry, Strategic Management Journal, 15 (1), $1-20$

97. Thomas, A. B. (1988). Does leadership make a difference to organizational performance? Administrative Science Quarterly, 33 (3), 388-400.

98. Tung, R. L. (1979). Dimensions of Organizational Environments: An Exploratory Study of their Impact on Organizational Structure. Academy of Management Journal, 22 (4), 672-93 
99. Van de Ven, A., \& Poole, M. S. (1995). Explaining Development and Change in Organizations, Academy of Management Review, 20 (3), 510-540.

100. Van Dut, V., (2015). The Effects of Local Business Environments on SMEs' Performance: Empirical Evidence from the Mekong Delta. Asian Academy of Management Journal, 20 (1), 101122

101. Venkatraman, N., \& Ramanujam, V., (1986). Measurement of Business Performance in Strategy Research: A Comparison of Approaches. Academy of Management Review, 11(4), 801-814 102. Virany, B., Tushman, M. L., \& Romanelli, E., (1992).

Executive Succession and Organization Outcomes in Turbulent Environments: An Organization Learning Perspective.

Organization Science, 3 (1), 72-9

103. Waldman, D. A., Bass, B. M., \& Yammarino, F. J., (1990). Adding to ContingentReward Behavior. The Augmenting Effect of Charismatic Leadership. Group \& Organization

Management, 15(4), 381 - 394

104. Wang, G., Holmes Jr. R. M., Oh, I. S., \& Zhue, W., (2016). Do CEOs Matter to Firm Strategic Actions and Firm Performance? A Meta Analytic Investigation Based on Upper Echelons Theory. Personnel Psychology, 69 (4), 775 - 862

105. Wang, G., Oh, I. S., Courtright, S. H., \& Colbert, A. E., (2011). Transformational Leadership and Performance across Criteria and Levels: A Meta-Analytic Review of 25 Years of Research. Group \& Organization Management, 36(2), 223-270.

106. Weber, R., Camerer, C., Rottenstreich, Y., \& Knez, M. (2001). The Illusion of Leadership: Misattribution of Cause in Coordination Games. Organization Science, 12(5), 582-598.

107. Weick, K. E., \& Quinn, R. E., (1999). Organizational Change and Development. Annual Review of Psychology, 50 (1), 361-386.

108. Witts, J. O., (2016). The Role of Strategic Leadership in Banking Profitability. (Unpublished Doctoral Thesis). College of Management and Technology.Walden University, South Africa 109. Wren, J., \& Dulewicz, V., (2005). Leader Competencies, Activities and Successful Change in The Royal Air Force. Journal of Change Management, 5(3), 295-309.

110. Yuchtman, E. \& Seashore, S. E., (1967). A System Resource Approach to Organizational Effectiveness, American Sociological Review, 32 (6), 891-903. 
111. Zhang, Y., \& Rajagopalan, N., (2010). Once an Outsider, Always an Outsider? Ceo Origin, Strategic Change, and Firm Performance. Strategic Management Journal, 31 (3), 334-346

112. Zajac, E. J., \& Kraatz, M. S., (1993). A Diametric Forces Model of Strategic Change: Assessing The Antecedents and Consequences of Restructuring in The Higher Education Industry. Strategic Management Journal, 14: 83-121 